\title{
Tracing the origin and species identity of Quercus robur and Quercus petraea in Europe: a review
}

\author{
By C. BlanC-JoliveT ${ }^{1), *)}$ and M. LiesebaCH ${ }^{1)}$
}

(Received $4^{\text {th }}$ September 2015)

\begin{abstract}
Traceability of forest material has received recently increasing interest and European regulations already apply on forest reproductive material and timber. DNA fingerprinting methods allow identification of species and control of geographic origin, providing that genetic reference data is available. In this review, we focus on the two economically important European oak species, Quercus robur and Q. petraea. We describe the available molecular markers and data, and discuss their applicability for traceability systems of forest reproductive material at a European scale. We also provide insights on the use of DNA fingerprinting on timber material.
\end{abstract}

Keywords: Quercus, oak, molecular markers, traceability, Europe, forest reproductive material, timber

\section{Introduction}

During the last decades, there has been increasing interest in conservation and use of genetic resources in Europe. In particular, new European regulations imply that traded forest reproductive material (EU Council Directive 1999/105/EC; German Act on Forest Reproductive Material) and timber (EU Timber Regulation 995/2010) are of known origin. Traceability of forest reproductive material (FRM) is of significant importance, as it might avoid afforestation with maladapted material and therefore prevent the establishment of material unsuitable for the local environmental conditions. In some countries like Germany, traceability systems have been already set up to control seed lots at different steps along the chain of custody (KoNNERT, 2006; KONNERT and HUSSENDÖRFER, 2002). In this paper, we review and discuss

1) Thünen Institute of Forest Genetics, Sieker Landstrasse 2, D-22927 Grosshansdorf.

*) Corresponding author: CÉLINE BlanC-Jolivet.

Tel. +49 4102696 157, Fax +49 4102696200.

E-Mail: celine.blanc-jolivet@thuenen.de existing DNA analysis methods and protocols which are in use for species identification and geographic traceability in the two European white oak species Quercus petraea (Matt.) Liebl. (sessile oak) and $Q$. robur L. (pedunculate oak). As identification of single logs is not relevant for the trade of white oaks, we do not discuss methods for individual identification. Furthermore, our aim is to provide guidelines for white oak tracing at the European scale.

Quercus robur and $Q$. petraea are common species in European temperate forests. Their distribution range is wide, from Ireland to Ukraine and from northern Spain to Southern Scandinavia (DuCOUsso and Bordacs, 2003), while $Q$. petraea does not occur naturally as far in the northeast as $Q$. robur (AAS, 2000, 2002). Reproductive maturity is reached at 20 to 40 years, and trees can live at least up to 800 years (AAS, 2000, 2002). The two European white oak species have the longest target rotation period of 160 years and more (KRAHL-URBAN, 1959). Both species are monoecious, anemophilous and mostly outcrossing (CHYBICKI and BURCZYK, 2013; GERBER et al., 2014; LAGACHE et al., 2013). Pollen dispersal kernels indicate both localized dispersal (mean 70-120 m) as well as fat tails representing long distance dispersal events, which translate in high rates of immigrant pollen within the studied stands (Buschвom et al., 2011; ChyBICKI and BuRCZYK, 2013; GERBER et al., 2014; LAGACHE et al., 2014; STREIFF et al., 1999). Seed dispersal is more restricted but long-distance dispersal events have also been inferred (GERBER et al., 2014; PETIT et al., 1997; STREIFF et al., 1998). Vegetative propagation has been enhanced in the past through coppicing for regeneration purposes. However, current management regimes favour natural regeneration and plantation, which are based on generative propagation. Therefore, traceability of forest reproductive material needs to be focused on seeds. Hybridization among $Q$. robur and $Q$. petraea in mixed stands has been reported in 
many studies, but with some asymmetry due to stronger interspecific sexual barriers in Q. petraea (CHYBICKI and BURCZYK, 2013; CURTU et al., 2007a; GERBER et al., 2014; LAGACHE et al., 2013, 2014; LEPAIS and GERBER, 2011), although signals of past asymmetric introgression toward $Q$. petraea could be observed at loci with high interspecific differentiation (GUICHOUX et al., 2013). Furthermore, both species seem to actively diverge from each other (GoicoecheA et al., 2012), which probably results in successful morphological and genetic identification of pure and hybrid individuals (CHYBICKI et al., 2010; CurTu et al., 2007a, b; ForTINI et al., 2015; GugERLI et al., 2007; GUICHOUX et al., 2011, 2013; NEOPHYTOU, 2014; NeOpHYtou et al., 2015; YÜCEDAG and GaILING, 2013).

Q. robur and $Q$. petraea are very common species in Europe, for which intensive seed transfer occurs. Oak timber is mostly used for building, furniture and barrel. Timber trade requires that the origin of the material is known, especially for certified timber from sustainably managed forests (for instance Forest Stewardship Council) and existing traceability systems are mostly based on paper documents, which could be falsified. Traceability systems based on DNA fingerprints, or at least controls along the chain of custody, could be useful to control declarations and thereby complement the existing traceability systems in order to avoid the plantation of maladapted seed stocks and the trade of illegally logged timber. Because existing studies on genetic traceability of white oaks are focusing on a small geographical scale (DEGEN et al., 2010; KonNERT, 2006; KonNERT and HussEndörFER, 2002) and do not take advantage of the large genetic data available in these species, we first review the available genetic methods and address their potential use for traceability purposes. Secondly, we discuss how a reliable, powerful, cost-effective and standardized genetic traceability system could be developed.

\section{General overview of existing DNA extraction protocols and genetic markers for the species}

\section{Material analysed and DNA extraction}

DNA has been successfully isolated from diverse material such as leaf (e.g. DuMOLIN et al., 1995), bud (e.g. Deguilloux et al., 2003b), cambium (e.g. DEGEN et al., 2010), the woody pericarp of the acorns (ZIEGENHAGEN et al., 2003), as well as timber (DEGUILloux et al., $2002,2003 \mathrm{~b}, 2004)$. DNA extraction protocols of wood material included a modified CTAB method (Dumolin et al., 1995) and the use of commercial DNA extraction kits like the Qiagen Plant Minikit (DEGuILloux et al., 2002).

\section{Molecular markers available}

Many authors report genetic variation at plastid markers, particularly in the chloroplast genome, as it allows studies at the continent level. Four universal cpDNA fragments have been extensively studied and has shown a longitudinal genetic differentiation resulting from postglacial colonization patterns over Europe (PETIT et al., 2002a, b; see also Table 1) as well as variation at the regional level (BALLIAN et al., 2010; BordaCs et al., 2002; CotTRELl et al., 2002; CsAiKL et al., 2002a, b; FINESCHI et al., 2002; JENSEN et al., 2002; KöNIG et al., 2002; Olalde et al., 2002; Petit et al., 1997, 2002c; SlADE et al., 2008). Genotyping was strongly facilitated by the development of PCR-RFLP techniques, which avoids expensive Sanger sequencing for genotyping at particular SNPs (Dumolin-Lapègue et al., 1998; Petit et al., $2002 \mathrm{~b})$. The combination of these chloroplast markers does not allow unambiguous identification of origin, as complex patterns occur at the regional level, but allows conformity testing (Deguilloux et al., 2003b; Kelleher et al., 2004; LowE et al., 2004; GAILING et al., 2007a, b). As cpDNA evolves clonally, there are similarities whatever the marker system used although the spatial resolution might differ. Some authors have used chloroplast microsatellites (GAILING et al., 2007a, b) developed by DEGUILloux et al. (2003a) or universal markers (SEBASTIANi et al., 2004; WEISING and GARDNER, 1999) to adress the origin of a planted stand or to genetically characterize a specific region (Table 1). Haplotypes derived from the cpSSRs and PCR-RFLP are strongly related, and cpSSRs show many rare alleles which could be used at a local scale for traceability purposes (Chmielewski et al., 2015).

By contrast, only a few studies report variation at mitochondrial markers (DUMOLINLAPEGUE et al., 1998, 1999). Mitochondrial DNA is maternally inherited in oaks, like cpDNA, 
and both genomes were shown to provide largely congruent results (DUMOLIN-LAPEGUE et al., 1998).

At the regional or local scale, nuclear markers are needed to study genetic structure. Up to 13 isozyme loci have been used for genetic studies in Quercus (DEGEN et al., 1999; HeRTEL and DEgen, 2000; Konnert et al., 2004; MÜLleRSTARCK et al., 1993; ZANETTO et al., 1994). These markers revealed a broad genetic structure despite low levels of among-population differentiation (ZANETTO et al., 1994). However, GREGORIUS genetic distances were found to be high among seed lots in Germany (MÜLLER-STARCK et al., 1993). As expected, microsatellites (SSRs, Single Sequence Repeats) have a higher genetic diversity (e.g. DEGEN et al., 1999), which provides more resolution. Indeed, two nuclear mul- tiplex sets of microsatellite loci [one 8-plex nSSRs set (nuclear) and a 12-plex eSSRs set (Expressed Sequence Tags SSRs (EST)] were recently developed by Guichoux et al. (2011), and were optimized for reproducibility and absence of null alleles. nSSRs have been substantially used for pollen flow studies, as their strong polymorphism allows reliable paternity estimation (BusCHBOM et al., 2011; LAGACHE et al., 2013; LePAis and Gerber, 2011; StreifF et al., 1999). Also many nSSRs have been until now the markers of choice to study the mating system, pollen dispersal and hybridization (Buschbom et al., 2011; ChyBICKI and BurCZYK, 2013; CurTu et al., 2007a; GERBER et al., 2014; LAGACHE et al., 2013, 2014; LEPAIS and GERBER, 2010; Petit et al., 1997; Streiff et al., 1998, 1999). Available nSSRs loci for $Q$. petraea and Q. robur are reviewed in Table 2 .

Table 1. - Organelle molecular markers available for Q. robur and Q. petraea for traceability purposes.

\begin{tabular}{|c|c|c|c|c|}
\hline Fragment & Type & Genotyping method & Spatial scale & Reference \\
\hline$m \cdots \mathrm{D}-t m \mathrm{I}$ & Chloroplast & l'CR-RFLP $^{\prime}$ & Euloperkegion & 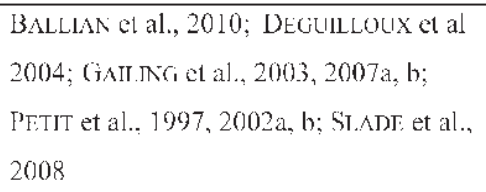 \\
\hline psaA-trns & Chloroplast & PCR-RFLP & Furope Region & 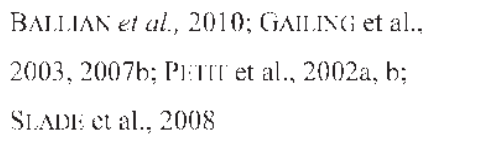 \\
\hline $\operatorname{psb}(-\operatorname{Trn} \mathrm{C})$ & Chloroplast & PCR-Rl'LP' & LuropeiRegion & $\begin{array}{l}\text { BALLAR al al, } 2010 ; \text { PEIT ct al, } 2002 a_{4} \\
\text { b; SLADI: ct al., } 2008\end{array}$ \\
\hline $\operatorname{trn} T-\operatorname{trn} F$ & Cbloroplast & PCR-RFLP & Lubope'Region & 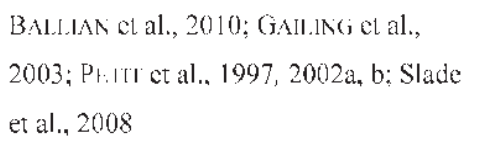 \\
\hline $\tan (-\tan 3)$ & Chloroplast & PCR-RFLP & Region & 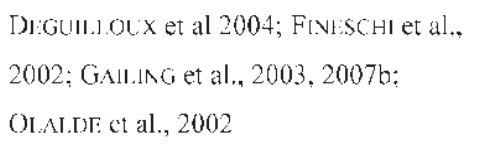 \\
\hline $\operatorname{trnL}(\mathrm{LAA}) 3^{\circ}-\operatorname{tm} \mathrm{t}^{\prime}(\mathrm{GAA})$ & Chloroplast & PCR-Rl'LP & Rcgion & $\begin{array}{l}\text { DrGull.106 ot al 2004; GNIINGet al., } \\
\text { 2007a }\end{array}$ \\
\hline ccrmp $2, \operatorname{comp} \theta$, complo & chloroplast & Fragrenent leogghth & Region & 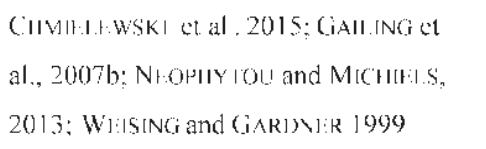 \\
\hline $\begin{array}{l}. . \mathrm{cd} 4 . \mu \mathrm{d} 5, \mu \mathrm{dt} l, \mu \mathrm{dt} 3, \mu \mathrm{dt} 4, . . \mathrm{kk} 3, \\
\mu \mathrm{kk} 4\end{array}$ & C. Floroplast & Firagment leggeth & Region & 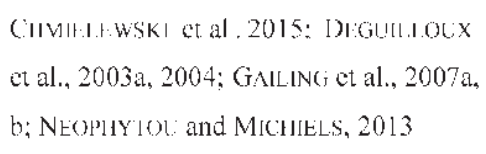 \\
\hline $\begin{array}{l}\text { cmes5, cmes6, amcs7, cmess, } \operatorname{cmes} 9 \text {, } \\
\text { cmes } 12\end{array}$ & & & & $\begin{array}{l}\text { CHMLLEWSKl te al , } 2015 ; \text { SEBASLINN el } \\
\text { al., } 2004\end{array}$ \\
\hline nad4-1:2 & Mitochondrial & PCR-Rl'LP & Region & DAMOIIR-LAPEGUE al al., 1998 \\
\hline $\operatorname{nad} 4-2 / 3$ & Mitochondrial & PCR-RlLP_SSCP & Rcojon & DHMOIN-LAPEGIJF ct al., 1998 \\
\hline
\end{tabular}


Table 2. - Nuclear microsatellite loci available for Q. robur and Q. petraea.

\begin{tabular}{|c|c|c|c|}
\hline Loci & Type & Developed by & References \\
\hline 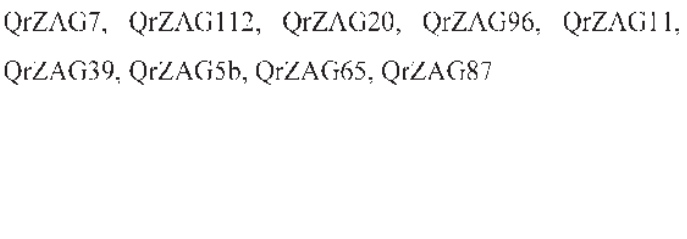 & $\operatorname{gSSR}$ & KAMPLER et al. (1998) & 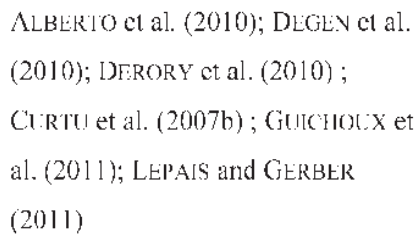 \\
\hline $\mathrm{MsQ} 13$ & gSSR & Dow et al. (1995) & $\begin{array}{l}\text { ALBERTO et al. (2010); ClRTl: et al. } \\
(2007 b) ; \text { DERORY ct al. }(2010) \text { : } \\
\text { GrJCHOl'X et al. (2011) }\end{array}$ \\
\hline $\begin{array}{l}\text { QpZAG15, QpZAG110, QpZAG46, QpZAG9, QpZAG36, } \\
\text { Qp/AG1/5, Qp/AG104 }\end{array}$ & gSSSR & STEINKELL.VER et al. (1997) & 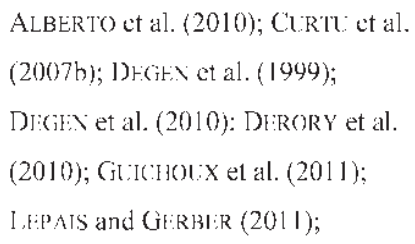 \\
\hline $\begin{array}{l}\text { PIE020, PIE223, PIE152, PIE242, PIE102, PIE243, PIE239, } \\
\text { PIE227, PIE271, P[E267, PIE258, PIE215 }\end{array}$ & eSSR & DLRAND et al. (2010) & 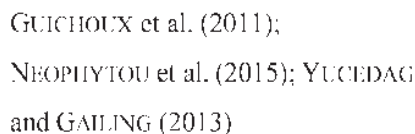 \\
\hline
\end{tabular}

In the last decade, next-generation sequencing methods allowed development of a large amount of SNP markers, for example to study adaptive variation at candidate genes (DERORY et al., 2010; GAILING et al., 2009). These markers have been recently used to differentiate the two oak species $Q$. petraea and $Q$. robur (Guichoux et al., 2013; VidALIS et al., 2013) and showed higher resolution than eight microsatellite loci (Guichoux et al., 2013). The publication of the complete genome of one $Q$. robur reference sample will strongly facilitate the development of SNP markers in the next years (PlOMION et al., 2015) and a SNP array has been recently published (LEPOITTEVIN et al., 2015).

\section{Allele scoring methods}

The genotyping methods for fragment analysis were strongly improved over the last decades. In the past, agarose or polyacrylamide gels were used for the screening of SNP variation through PCR-RFLP (BALLIAN et al., 2010; Curtu et al., 2007b; Deguilloux et al., 2003b, 2004; Dumolin-LAPÈGUe et al., 1998; GAILING et al., 2003, 2009; PETIT et al., 2002b; SLADE et al., 2008) or for microsatellite genotyping (BAKKER et al., 2003; DEGEN et al., 1999). Nowadays, separation on capillary sequencers allows multiplexing of up to 12 micrsatellite loci (ALBERTO et al., 2010; Buschbom et al., 2011; Degen et al., 2010; Derory et al., 2010; GAILING et al., 2007b; GugerLi et al., 2007; Guichoux et al., 2011; HoeltKen et al., 2012; LePAis and Gerber, 2011; VidALIS et al., 2013), which reduces the genotyping costs and strongly improve the sensitivity in case of poor amplification. Besides Sanger sequencing (DERORY et al., 2010), new SNP genotyping methods have been tested, such as a GoldenGate assay (Illumina Inc.) (Guichoux et al., 2013), a Illumina Infinium iSelect Custom Genotyping Array (LEPOITTEviN et al., 2015) or by a SNaPshot procedure running on an capillary sequencer (VIDALIS et al., 2013). Other methods, such as the MassARRAY technology are also available and are very promising for low-quality template DNA, such as timber (BLANC-JOLIVET, GUICHOUX, personal observation). A formal comparison of the different SNP scoring methods would be necessary to find the most appropriate technology for the screening of poor-quality DNA material, as it is often the case for material to trace.

\section{Levels of differentiation and their use for traceability systems}

Strong differentiation occurs throughout Europe at cpDNA markers, which were interpreted in the light of species history and post- 
glacial recolonization routes (PETIT et al., 2002a; Neophytou and Michiels, 2013). Although a strong correlation has been observed between cpDNA and nuclear genetic variation (KREMER et al., 2002), pollen flow results in reduction of original differentiation pattern (FINKELDEY and MATYAS, 2003). Levels of differentiation at nuclear markers are on average low $\left(\mathrm{G}_{\mathrm{st}}=0.022\right.$ in $Q$. robur; $\mathrm{G}_{\mathrm{st}}=0.031$ in $Q$. petraea) compared to chloroplast markers $\left(\mathrm{G}_{\mathrm{st}}=0.781\right.$ in $Q$. robur; $\mathrm{G}_{\mathrm{st}}=0.856$ in Q. petraea) (PETiT et al., 2004). However, the high polymorphism at microsatellite markers probably results in the underestimation of differentiation (HEDRICK, 2005). Studies involving nuclear markers at a European scale are rare, as these markers require at least 30 samples per population and present problems of data standardization, therefore hindering collaboration among laboratories to set up large datasets. At set of 125 SNPs detected at nine candidate genes did not yield stronger among population differentiation than a set of 15 microsatellite loci (DEGEN, personal communication). As expected, variation in levels of differentiation was also observed among oak species, indicating that some species are more closely related than others (CURTU et al., 2007b).

Two different marker systems have been tested until now for traceability purposes in oak. The cpDNA marker system described by Petit et al. (2002a) has been used to test the conformity of the declaration of origin of wood (DeGuilloux et al., 2003b). Given the low differentiation at the local scale and the tendency of oak species to share locally the maternal lineages, this system can typically only provide information on the region of origin, not on stand-level scale or on species. Other traceability systems are based on nuclear microsatellite markers and rely on the comparison of the genetic distance of the tested material (seed lot) with a reference sample from the declared stand of origin (KonNerT, 2006; KONNERT and HUSSENDÖRFER, 2002), or on assignment methods (DEGEN et al., 2010). The first method relies on the fact the genetic distance, based on eight microsatellite loci both for $Q$. robur and $Q$. petraea, among the test and reference samples is lower for the true stand of origin compared to other provenances. This traceability system is therefore very labour intensive, as sampling has to be repeated for each seed harvest. Further, this method has been imple- mented in forest tree species in Southern Germany, and little information is available on its statistical power. DEGEN et al. (2010) have shown that the origin of forest reproductive material (seedlings) can be successfully controlled with DNA fingerprints based on eight microsatellite loci. The genotypes of reproductive material were compared to data from adult individuals within the reference populations with assignment methods combined with exclusion tests (CORNUET et al., 1999; RANNALA and Mountain, 1997). The method was very powerful, as it allowed successful assignment at a very small geographic scale (DEGEN et al., 2010). Reference data based on microsatellite loci also provided good results for genetic traceability in other forest tree species, in particular to combat illegal logging. For example, theoretical assignment success was 51\%, 80\% and $90 \%$ for groups of one, two and three self-assigned samples at the forest concession level in the very low differentiated tropical species Entandrophragma cylindricum (JOLIVET and DEGEN, 2012). A blind test on timber samples also resulted in $86 \%$ correct control of the claim on the concession of origin. Similar results could be obtained with the Neotropical species Swietenia macrophylla (DEGEN et al., 2013), although the geographical scale was much larger and covered Central and Southern America. Genetic assignment methods are also commonly used on microsatellite data in plant (cannabis: HOWARD et al., 2009; palm: NAZARENO and DOS REIS, 2014), and animal species (cattle: MATEUs and Russo-Almeida, 2015; salmon: Glover et al., 2010; red deer: FRANTZ et al., 2006) for traceability or forensic purposes. A similar method to classical genetic assignment, but including geographical information, has been successfully applied to identify the main poaching hotspots of elephant ivory (WASSER et al., 2015). The use of genetic assignment methods with microsatellite data is therefore very reliable, providing that reference data, at least from the focus area is available.

Until now, no reference data for geographic traceability purposes based on nuclear SNPs, has been published in oak, although some data has been gathered at 82 SNPs for four Q. robur stands across Europe (VENDRAMIN et al., unpublished). Although genetic differentiation within species was not higher than with microsatellites, the move towards the use of SNPs for traceability is underway, as shown by the use of 
this marker type in several animal species (BEKKEVOLD et al., 2015; NEGRINI et al., 2008; OGDEN and LINACRE, 2015), and even in human (O'Dushlaine et al., 2010). Screening of large amount of loci, followed by selection of loci showing high genetic differentiation and/or outliers (BEKKEVOLD et al., 2015; GLOVER et al., 2010; OGDEN and LINACRE, 2015) might be a good strategy to develop cost-effective marker sets for genetic traceability. First results on Larix spp. are encouraging (BLANC-JOLIVET et al., in preparation).

\section{Discussion}

\section{Species identification}

Although hybridization among white oak species occurs, it is generally rare in mixed stands (CURTu et al., 2007a; GUGERLI et al., 2007). Phenotype variation such as leaf morphology and pubescence, and genetic analysis of adults and progenies among species occurring in sympatry showed that low inter-specific pollen-flow (CURTU et al., 2007a), backcross events (LEPAIS and GERBER, 2011), genetically controlled pollen discrimination (LEPAIS and GERBER, 2011), selection against hybrids at the juvenile stage (GUGERLI et al., 2007) and postmating prezygotic reproductive barriers (ABADIE et al., 2012; LAGACHE et al., 2013) have been identified as potential mechanisms maintaining species integrity. The two species have contrasting environmental optima (CHYBICKI et al., 2010; Guichoux et al., 2013; NeOphytou and MiCHIELS, 2013), different reproductive strategies (LAGACHE et al., 2014) and within-stand environmental heterogeneity sometimes affects the spatial arrangement of the two species (Chybicki and BurczyK, 2013; Gugerli et al., 2007; LAGACHE et al., 2013, 2014). Further, signatures of divergent selection have been identified (GoICOECHEA et al., 2012).

Co-dominant markers (isoenzymes and microsatellites) have been successfully applied to distinguish oak species (CURTU et al., 2007a, b; Gomory, 2000; Gugerli et al., 2007; GuICHOUX et al., 2011, 2013; HERTEL and DEGEN, 2000; HoeltKen et al., 2012; LePAis and GERBER, 2011). In contrast, cpDNA data provides virtually no information on species status for sympatric species (CURTU et al., 2007a; NEOPHYTOU and MICHIELS, 2013), suggesting that codominant nuclear markers are needed to indentify the species. Further, species identification in oak requires a substantial amount of data at microsatellite or at SNP loci over the distribution range, as geographic differentiation within species needs to be distinguished from between-species differentiation. Applying the set of loci as in Guichoux et al. (2013) over many well-dispersed European populations might be useful to build a reliable set of molecular markers for oak species identification of samples stemming from all Europe.

Another technical issue includes standardization of microsatellite data among laboratories. High polymorphism at most microsatellite loci (AlberTo et al., 2010; DEGEN et al., 2010) will not facilitate the establishment of large-scale data. Well-validated markers with reference samples and procedures are needed for this purpose (Guichoux et al., 2011).

\section{Geographical origin}

As discussed above, cpDNA markers could be useful to control the region of origin at a broad scale, and to check the conformity of a given material to its population of origin (DEGUILLOUX et al., 2003b; PETIT et al., 2002b). However, at a local scale, only nuclear microsatellite markers allow a reliable control of the origin, as most cpDNA $Q$. robur and $Q$. petraea haplotypes are widely distributed across Europe, although some haplotypes are restricted to a particular region (e.g. Slavonia, PETIT et al., 2002b; GAILING et al., 2007b). Microsatellite data for reference populations across the whole European range would therefore be needed to verify the geographical origin, at least for autochthonous material. This task would not be easy, as many populations are planted, and genetic exchanges between native forests and planted material probably occur (GAILING et al., 2007b; KÖNIG et al., 2002; NeOpHYTou and Michiels, 2013). In the frame of traceability of forest reproductive material where source stands are clearly identified, assignment methods applied on nSSRs data have however already provided very strong results (DEGEN et al., 2010). Estimation of exclusion probabilities for each putative stand of origin can reliably address whether the material possibly originates from one of several reference stands or from another stand (CORNUET et al., 1999). The second step is to find the most likely population among the stands exhibiting non-significant exclusion probability (JOLIVET and DEGEN, 2012). Although many studies pro- 
vided results on genetic assignment, only a subset used this two-step procedure (DEGEN et al., 2013; FrANTZ et al., 2006; HonJo et al., 2008; HowARD et al., 2009; Jolivet and DEGEN, 2012; MAUDET et al., 2002; NEGRINI et al., 2008), which provides high security in forensic applications, as the true origin might have not been sampled (MANEL et al., 2002). Other methods for exclusion testing include calculation of likelihood ratios (BEKKEVOLD et al., 2015; OGDEN and LINACRE, 2015). In other words, assignment methods associated with exclusion probabilities estimation can address the question - can the material originate from a given stand? - but the true origin will not be necessarily identified. However, in order to avoid a non-exclusion of too many reference populations or similar likelihood values, presence of genetic differentiation is required. Some studies addressed the power of the genetic assignment on their reference data to address its suitability for the questions raised. The authors concluded that several factors including strong genetic differentiation, polymorphism, number of reference samples per population and number of loci are affecting the outcome of assignment tests (BEKKEVOLD et al., 2015; GLOver et al., 2009; HowARD et al., 2009; MANEL et al., 2005; MAUDET et al., 2002). Also, the use of Bayesian clustering analysis to identity gene pools can substantially improve the accuracy of genetic assignment (BEKKEVOLD et al., 2015; GLOVER et al., 2009; MANEL et al., 2005; Mateus and Russo-Almeida, 2015) but identification at the stand level, as required for seed harvests, might be in this case not possible. Clustering analysis would therefore only be the method of choice for traceability at a regional level. A way to overcome this problem could be the use of group assignment, as shown in Quercus robur (DEGEN et al., 2010), Entandrophragma cylindricum timber (JOLIVET and Degen, 2012) and in Prunus avium, where seed stand of origin could be assigned with 99\% accuracy when assignment testing was conducted on groups of five individuals (BLANCJOLIVET, unpublished). Such very reliable methods should thus provide cost-effective ways to verify the origin of FRM.

Recently developed molecular marker development (RAD sequencing) and genotyping methods (MassARRAY) will facilitate the use of nuclear SNPs in genetic traceability systems. As shown by GuICHOUx et al. (2013), discrimination among $Q$. robur and $Q$. petraea was higher at 262 SNPs selected for high interspecific differentiation than at 12 SSRs. Efficient marker detection and screening methods will allow the setup of SNPs sets containing a strong geographical signal (OGDEN and LINACRE, 2015). Another advantage of SNP over SSR data is the straightforward standardization among laboratories and genotyping methods, which should make possible the development of large-scale datasets for reference stands.

During the last decades, tracing back timber to its region of origin has raised much interest as control tool against illegal logging. DNA from wood samples is highly fragmented and degraded, causing technical problems for DNA extraction and amplification. Template contamination is also frequent. Amplification of nuclear microsatellites in wood is complicated by allele drop-in and drop-out, contamination and nonamplification (BLANC-JOLIVET, personal observation, but see GILL et al., 2012). Also, cpSSRs which are based on fragment size variation of 1 bp should be avoided due to frequent shifts and/or genotyping errors during fragment analysis, which are sometimes related to the Taq Polymerase used for the PCR reaction (BlANC-JOLIVET, personal observation). Therefore, when chloroplast DNA is used, SNP markers or indels, which could be scored by PCR-RFLP and/or fragment analysis should be favoured. Further, allele identification is sometimes difficult due to low signal quality resulting in slight shifts. The use of well-designed SNP sets might therefore be an alternative to the use of SSR markers, as genotyping errors due to stuttering and shifts are impossible. Most researchers in the field thus concentrate on cpDNA, which is present in more copies per cell, resulting in higher and more reliable amplification. The traceability system based on cpDNA was successfully tested on wood material (DEGuILloux et al., 2004). Statistical tools only include conformity tests, which relies on available data on the population of origin and can only answer the question: is the genotype of the material conform to the genetic data from its declared origin? By contrast, assignment methods provide information on the most likely population of origin, providing that reference data exists, and can be used to control logs without any declaration. Unfortunately, most assignment methods have not been adapted yet to chloroplast data, which often violate the assumption of non-independency of loci. A new 
method combining markers into haplotypes seem to be promising, because the assumptions of independency and linkage equilibrium among loci are not required (DUFORET-FREBOURG et al., 2015). However, high fragmentation of data due to amplification failure from timber samples might not allow haplotype construction.

\section{Conclusion}

This review shows that a lot of genetic data is available for Quercus, and that two markers systems can be used for traceability studies. One system includes cpDNA markers characterized over the whole distribution range in Europe, while the other uses nuclear co-dominant markers with only limited information across the European distribution range. Although statistical tools have been well implemented and successfully tested at low spatial scale for microsatellites, this type of data requires strong standardization among laboratories. In fact, fragment size varies among machines and binning of alleles might therefore be different among laboratories. Furthermore, the high polymorphism in $Q$. robur and $Q$. petraea at this type of markers might exacerbate these difficulties. Intensive work is thus needed on the standardization of microsatellite data. Alternatively, SNP data might become the marker of choice to trace back fresh FRM material (seeds, seedlings, adults) and perhaps eventually wood material to its stand of origin, providing that the number of loci to screen is not too large. Efficient marker selection methods might support the development of markers sets for each specific traceability question.

The marker system based on cpDNA is currently the most suitable to trace low-quality DNA material such as timber. However, this marker system should be further developed to increase spatial resolution based on SNP markers or indels over Europe, to shorten DNA fragment size in order to increase amplification success, to find allele redundancies which would help overcoming the problems with poor DNA amplification on timber and to allow multiplexing of loci. Next-generation sequencing technologies could be useful to detect spatially structured polymorphism in the chloroplast, mitochondrial or nuclear genomes. However, more work is required on statistical tools to allow the development of powerful tests on haplotype data. Robust SNP genotyping methods such as the MassARRAY technology might make also the use of nuclear markers possible for timber tracking, which would overcome the statistical and lack of polymorphism problems of plastid markers.

\section{Acknowledgements}

We would like to thank RÉmy PETIT and two anonymous reviewers for constructive comments on the manuscript. This work was carried out within WP7 "Towards the development of a platform for fingerprinting and traceability of biological material" of the EU-project "Designing trees for the future". The research leading to these results has received funding from the European Union's Seventh Framework Programme for research, technological development and demonstration under grant agreement $n^{\circ} 284181$ ("Trees4Future"). The contents of this publication reflect only the author's views and the European Union is not liable for any use that may be made of the information contained therein.

\section{References}

AAS, G. (2000): Quercus petraea (Mattuschka) Lieblein, 1784. In: H. WeISGERBER; A. ROLOFF; U. LANG and B. Stimm (eds.): Enzyklopädie der Holzgewächse. Handbuch und Atlas der Dendrologie. Weinheim. Wiley-VCH Verlag. 20. Erg.Lfg. 6/00. 15 pp.

AAS, G. (2002): Quercus robur L., 1953. In: H. WeISGERBER; A. ROLOFF; U. LANG and B. STIMm (eds.): Enzyklopädie der Holzgewächse. Handbuch und Atlas der Dendrologie. Weinheim. Wiley-VCH Verlag. 30. Erg.Lfg. 12/02. 14 pp.

Abadie, P., G. Roussel, B. Dencausse, C. Bonnet, E. BERTOCCHI and J-M. LOUveT et al. (2012): Strength, diversity and plasticity of postmating reproductive barriers between two hybridizing oak species (Quercus robur L. and Quercus petraea (Matt.) Liebl.). Journal of Evolutionary Biology 25: 157-173.

Alberto, F., J. Niort, J. Derory, O. Lepais, R. Vitalis and D. GaLOP et al. (2010): Population differentiation of sessile oak at the altitudinal front of migration in the French Pyrenees. Molecular Ecology 19: 2626-2639.

BAKKer, E. G., B. C. VAN DAM, F. A. VAN EeUwiJK and E. JACOBSEN (2003): Population genetics of indigenous Quercus robur L. populations and of derived half-sib families has implications for the reproductive management of the species. Plant Biology 5: 393-399. 
Ballian, D., M. Ivankovic, J. Gracan, S. Peric, H. MARJANOvic and M. Bobinac et al. (2010): Analysis of pubescent oak (Quercus pubescens Willd.) By means of chloroplast dna (cpDNA) in the western part of the balkan peninsula. Acta Societatis Botanicorum Poloniae 79: 189-195.

Bekkevold, D., S. J. Helyar, M. T. Limborg, E. E. Nielsen, J. Hemmer-Hansen, L. A. W. Clausen, G. R. Carvalho and C. FishPopTrace (2015): Gene-associated markers can assign origin in a weakly structured fish, Atlantic herring. Ices Journal of Marine Science 72: 1790-1801.

Bordacs, S., F. Popescu, D. Slade, U.M. Csaikl, I. LESUR and A. Borovics et al. (2002): Chloroplast DNA variation of white oaks in northern Balkans and in the Carpathian Basin. Forest Ecology and Management 156: 197-209.

Buschbom, J., Y. YANBAev and B. Degen (2011): Efficient Long-Distance Gene Flow into an Isolated Relict Oak Stand. Journal of Heredity 102: 464-472.

Chmielewski, M., K. Meyza, I. J. Chybicki, A. Dzialuk, M. Litkowiec and J. BurczyK (2015): Chloroplast microsatellites as a tool for phylogeographic studies: the case of white oaks in Poland. Iforest-Biogeosciences and Forestry 8: 765-771.

ChyBicki, I. J. and J. BurczyK (2010): Realized gene flow within mixed stands of Quercus robur L. and $Q$. petraea (Matt.) L. revealed at the stage of naturally established seedling. Molecular Ecology 19: 2137-2151.

Chybicki, I. J. and J. BurczyK (2013): Seeing the forest through the trees: comprehensive inference on individual mating patterns in a mixed stand of Quercus robur and $Q$. petraea. Annals of Botany 112: 561-574.

Cornuet, J. M., S. Piry, G. Luikart, A. Estoup and M. Solignac (1999): New methods employing multilocus genotypes to select or exclude populations as origins of individuals. Genetics 153: 1989-2000.

Cottrell, J. E., R. C. Munro, H. E. Tabbener, A. C. M. Gillies, G. I. Forrest and J. D. Deans et al. (2002): Distribution of chloroplast DNA variation in British oaks (Quercus robur and Q. petraea): the influence of postglacial colonisation and human management. Forest Ecology and Management 156: $181-195$.

Csaikl, U. M., K. Burg, S. Fineschi, A. O. König, G. Matyas and R. J. Petit (2002a): Chloroplast DNA variation of white oaks in the alpine region. Forest Ecology and Management 156: 131-145.

Csaikl, U. M., I. Glaz, V. Baliuckas, R. J. Petit and J. S. JENSEN (2002b): Chloroplast DNA variation of white oak in the Baltic countries and Poland. Forest Ecology and Management 156: 211-222.

Curtu, A. L., O. Gailing and R. Finkeldey (2007a): Evidence for hybridization and introgression within a species-rich oak (Quercus spp.) community. Bmc Evolutionary Biology 7: 218.
Curtu, A. L., O. Gailing, L. Leinemann and R. FINKELDEY (2007b): Genetic variation and differentiation within a natural community of five oak species (Quercus spp.). Plant Biology 9: 116-126.

Degen, B., A. Holtken and M. RogGe (2010): Use of DNA-Fingerprints to Control the Origin of Forest Reproductive Material. Silvae Genetica 59: 268-273.

Degen, B., R. Streiff and B. Ziegenhagen (1999): Comparative study of genetic variation and differentiation of two pedunculate oak (Quercus robur) stands using microsatellite and allozyme loci. Heredity 83: 597-603.

Degen, B., S. E. Ward, M. R. Lemes, C. Navarro, S. Cavers and A. M. Sebbenn (2013): Verifying the geographic origin of mahogany (Swietenia macrophylla King) with DNA-fingerprints. Forensic Science International-Genetics 7: 55-62.

Deguilloux, M. F., S. Dumolin-Lapegue, L. Gielly, D. GRIVET and R. J. Petit (2003a): A set of primers for the amplification of chloroplast microsatellites in Quercus. Molecular Ecology Notes 3: 24-27.

Deguilloux, M. F., M. H. Pemonge, L. Bertel, A. Kremer and R. J. Petit (2003b): Checking the geographical origin of oak wood: molecular and statistical tools. Molecular Ecology 12: 1629-1636.

Deguilloux, M. F., M. H. Pemonge and R. J. Petit (2002): Novel perspectives in wood certification and forensics: dry wood as a source of DNA. Proceedings of the Royal Society B-Biological Sciences 269: 1039-1046.

Deguilloux, M. F., M. H. Pemonge and R. J. Petit (2004): DNA-based control of oak wood geographic origin in the context of the cooperage industry. Annals of Forest Science 61: 97-104.

Derory, J., C. Scotti-Saintagne, E. Bertocchi, L. Le Dantec, N. Graignic and A. Jauffres et al. (2010): Contrasting relationships between the diversity of candidate genes and variation of bud burst in natural and segregating populations of European oaks. Heredity 104: 438-448.

Dow, B. D., M. V. Ashley and H. F. Howe (1995): Characterization of highly variable $(\mathrm{GA} / \mathrm{CT})(\mathrm{n})$ microsatellites in the bur oak, Quercus-macrocarpa. Theoretical and Applied Genetics 91: 137-141.

Ducousso, A. and S. Bordacs (2004): EUFORGEN Technical Guidelines for genetic conservation and use for pedunculate and sessile oaks (Quercus robur and $Q$. petraea). International Plant Genetic Resources Institute, Rome, Italy. 6 pp.

Duforet-Frebourg, N., L. M. Gattepaille, M. G. B. BLUM and M. JAKOBSSON (2015): HaploPOP: a software that improves population assignment by combining markers into haplotypes. BMC Bioinformatics 16: 242.

Dumolin-Lapegue, S., A. Kremer and R. J. Petit (1999): Are chloroplast and mitochondrial DNA variation species independent in oaks? Evolution 53: $1406-1413$. 
Dumolin-Lapegue, S., M. H. Pemonge and R. J. Petit (1998): Association between chloroplast and mitochondrial lineages in oaks. Molecular Biology and Evolution 15: 1321-1331.

Dumolin, S., B. Demesure and R. J. Petit (1995): Inheritance of chloroplast and mitochondrial genomes in pedunculate oak investigated with an efficient PCR method. Theoretical and Applied Genetics 91: 1253-1256.

Durand, J., Bodenes, C. and Chancerel E. et al. (2010): A fast and cost-effective approach to develop and map EST-SSR markers: oak as a case study. BMC Genomics 11: 570.

Fineschi, S., D. Taurchini, P. Grossoni, R. J. Petit and G. G. Vendramin (2002): Chloroplast DNA variation of white oaks in Italy. Forest Ecology and Management 156: 103-114.

Finkeldey, R. and G. MATYAS (2003): Genetic variation of oaks (Quercus spp.) in Switzerland. 3. Lack of impact of postglacial recolonization history on nuclear gene loci. Theoretical and Applied Genetics 106: 346-352.

Fortini, P., P. Di Marzio and R. Di Pietro (2015): Differentitation and hybridization of Quercus frainetto, Q. petraea, and $Q$. pubescens (Fagaceae): insights from macro-morphological leaf traits and molecular data. Plant Systematics and Evolution 301: 375-385.

Frantz, A. C., J. T. Pourtois, M. Heuertz, L. Schley, M. C. Flamand, A. Krier, S. Bertouille, F. Chaumont and T. Burke (2006): Genetic structure and assignment tests demonstrate illegal translocation of red deer (Cervus elaphus) into a continuous population. Molecular Ecology 15: 3191-3203.

Gailing, O., B. Vornam, L. Leinemann and R. FINKELDEY (2009): Genetic and genomic approaches to assess adaptive genetic variation in plants: forest trees as a model. Physiologia Plantarum 137: 509-519.

Gailing, O., H. Wachter, J. Heyder, H. P. Schmittz and R. FINKELDEY (2007a): Chloroplast DNA analysis in oak stands (Quercus robur L.) in North Rhine-Westphalia with presumably Slavonian origin: Is there an association between geographic origin and bud phenology? Journal of Applied Botany and Food Quality-Angewandte Botanik 81: 165-171.

Gailing, O., H. Wachter, L. Leinemann, B. Hosius, R. FINKELDEY and H. P. SChMitT et al. (2003): Characterisation of different provenances of late flushing pedunculate oak (Quercus robur L.) with chloroplast markers. Allgemeine Forst- und Jagdzeitung 174: 227-231.

Gailing, O., H. Wachter, H. P. Schmitt, A. L. Curtu and R. FINKELDEY (2007b): Characterization of different provenances of Slavonian pedunculate oaks (Quercus robur L.) in Munsterland (Germany) with chloroplast DNA markers: PCR-RFLPs and chloroplast microsatellites. Allgemeine Forst- und Jagdzeitung 178: 85-90.
Gerber, S., J. Chadoeuf, F. Gugerli, M. Lascoux, J. Buiteveld and J. Cottrell et al. (2014): High rates of Gene Flow by Pollen and Seed in Oak Populations across Europe. PlosOne 9: e85130.

Gill, P., L. Gusmao, H. Haned, W. R. Mayr, N. Morling, W. Parson, L. Prieto, M. Prinz, H. Schneider, P. M. Schneider and B. S. Weir (2012): DNA commission of the International Society of Forensic Genetics: Recommendations on the evaluation of STR typing results that may include drop-out and/or drop-in using probabilistic methods. Forensic Science International-Genetics 6: 679-688.

Glover, K. A., M. M. Hansen, S. Lien, T. D. Als, B. Hoymeim and O. SkaAla (2010): A comparison of SNP and STR loci for delineating population structure and performing individual genetic assignment. BMC Genetics 11: (6 January 2010)-(2016 January 2010).

Goicoechea, P. G., R. J. Petit and A. Kremer (2012): Detecting the footprints of divergent selection in oaks with linked markers. Heredity 109: 361-371.

Gomory, D. (2000): A gene coding for a non-specific NAD-dependent dehydrogenase shows a strong differentiation between Quercus robur and Quercus petraea. Forest Genetics 7: 167-170.

Gugerli, F., J. C. Walser, K. Dounavi, R. HolderEGGER and R. FINKELDEY (2007): Coincidence of small-scale spatial discontinuities in leaf morphology and nuclear microsatellite variation of Quercus petraea and $Q$. robur in a mixed forest. Annals of Botany 99: 713-722.

Guichoux, E., L. Lagache, S. Wagner, P. Leger and R. J. Petit (2011): Two highly validated multiplexes (12-plex and 8-plex) for species delimitation and parentage analysis in oaks (Quercus spp.). Molecular Ecology Resources 11: 578-585.

Guichoux, E., P. GARnier-Gere, L. LAGache, T. LANG, C. Boury and R. J. Petit (2013): Outlier loci highlight the direction of introgression in oaks. Molecular Ecology 22: 540-462.

HEDRICK, P. W. (2005): A standardized genetic differentiation measure. Evolution 59: 1633-1638.

Hertel, H. and B. DEGEN (2000): Unterscheidung von Stiel- und Traubeneichen (Quercus robur L. und $Q$. petraea [Mattuschka] Liebl.) mit Hilfe von genetischen und morphologischen Merkmalen. For. Snow Landsc. Res. 75, 1/2: 169-183.

Hoeltken, A. M., J. Buschbom and R. Kaetzel (2012): Die Artintegrität unserer heimischen Eichen Quercus robur L., Q. petraea (Matt.) Liebl. und $Q$. pubescens Willd. aus genetischer Sicht. Allgemeine Forst- und Jagdzeitung 183: 5/6

Honjo, M., S. Ueno, Y. Tsumura, T. Handa, I. WASHITANI and R. OHSAWA (2008): Tracing the origins of stocks of the endangered species Primula sieboldii using nuclear microsatellites and chloroplast DNA. Conservation Genetics 9: 1139-1147.

Howard, C., S. GIlmore, J. Robertson and R. Peakall (2009): A Cannabis sativa STR Genotype Database for Australian Seizures: Forensic 
Applications and Limitations. Journal of Forensic Sciences 54: 556-563.

Jensen, J. S., A. Gillies, U. Csaikl, R. Munro, S. F. MADSEn and H. Roulund et al. (2002): Chloroplast DNA variation within the Nordic countries. Forest Ecology and Management 156: 167-180.

Jolivet, C. and B. DEGEN (2012): Use of DNA fingerprints to control the origin of sapelli timber (Entandrophragma cylindricum) at the forest concession level in Cameroon. Forensic Science Internation: Genetics 6: 487-493.

Kampfer, S., C. Lexer, J. Glossl and H. SteinKELLNER (1998): Characterization of (GA)(n) microsatellite loci from Quercus robur. Hereditas 129: 183-186.

Kelleher, C. T., T. R. Hodkinson, D. L. Kelly and G. C. Douglas (2004): Characterisation of chloroplast DNA haplotypes to reveal the provenance and genetic structure of oaks in Ireland. Forest Ecology and Management 189: 123-131.

König, A. O., B. Ziegenhagen, B. C. Van Dam, U. M. CsaikL, E. CoArt and B. Degen et al. (2002): Chloroplast DNA variation of oaks in western Central Europe and genetic consequences of human influences. Forest Ecology and Management 156: 147-166.

KonNERT, M. (2006): Erfolge beim Herkunftsnachweis mittels Isoenzym- und DNA-Analysen. AFZDerWald 61: 430-432.

Konnert, M. and E. Hussendörfer (2002): Herkunftssicherung bei forstlichem Vermehrungsgut durch Referenzproben. Allgemeine Forst- und Jagdztg. 6: 97-104.

Konnert, M., M. Fromm and T. Wimmer (2004): Anleitung für Isoenzymuntersuchungen bei Stieleiche (Quercus robur) und Traubeneiche (Quercus petraea) - Anleitungen zur Trennmethodik und Auswertung der Zymogramme. https://blag-fgr.genres.de//fileadmin/SITE_GENRES/downloads/docs/ BLAG/stieleiche-arbeitsanleitung.pdf (27.08.2015)

Krahl-URBan, J. (1959): Die Eichen. Verlag P. Parey, Berlin, Hamburg. 288 pp.

Kremer, A., J. Kleinschmit, J. Cottrell, E. P. CunDALL, J. D. DEANS and A. Ducousso et al. (2002): Is there a correlation between chloroplastic and nuclear divergence, or what are the roles of history and selection on genetic diversity in European oaks? Forest Ecology and Management 156: 75-87.

Lagache, L., E. K. Klein, A. Ducousso and R. J. PETIT (2014): Distinct male reproductive strategies in two closely related oak spcecies. Molecular Ecology 23: 4331-4343.

Lagache, L., E. K. Klein, E. Guichoux and R. J. PETIT (2013): Fine-scale environmental control of hybridization in oaks. Molecular Ecology 22: $423-436$.

LEPAIS, O. and S. GERBER (2011): Reproductive patterns shape introgression dynamics and species succession within the European white oak species complex. Evolution 65: 156-170.
Lepoittevin, C., C. Bodenes, E. Chancerel, L. VilLAte, T. LANG, I. Lesur, C. Boury, F. Ehrenmann, D. Zelenica, A. Boland, C. Besse, P. GarnierGere, C. Plomion and A. Kremer (2015): Singlenucleotide polymorphism discovery and validation in high-density SNP array for genetic analysis in European white oaks. Molecular Ecology Resources 15: 1446-1459.

Lowe, A., R. Munro, S. SAmuel and J. Cottrell (2004): The utility and limitations of chloroplast DNA analysis for identifying native British oak stands and for guiding replanting strategy. Forestry 77: 335-347.

MANEL, S., P. Berthier and G. LuIKART (2002): Detecting wildlife poaching: Identifying the origin of individuals with Bayesian assignment tests and multilocus genotypes. Conservation Biology 16: 650-659.

Manel, S., O. E. GagGiotti and R. S. WAPles (2005): Assignment methods: matching biological questions techniques with appropriate. Trends in Ecology \& Evolution 20: 136-142.

Mateus, J. C. and P. A. Russo-AlmeidA (2015): Traceability of 9 Portuguese cattle breeds with PDO products in the market using microsatellites. Food Control 47: 487-492.

Maudet, C., G. Luikart and P. Taberlet (2002): Genetic diversity and assignment tests among seven French cattle breeds based on microsatellite DNA analysis. Journal of Animal Science 80: 942-950.

Müller-Starck, G., S. Herzog and H. Hattemer (1993): Intra- and interpopulational genetic variation in juvenile populations of Quercus robur L. and Quercus petraea Liebl. Annals of Forest Science 50: $233 \mathrm{~s}-244 \mathrm{~s}$.

NAzARENo, A. G. and M. S. DOs ReIs (2014): Where did they come from? Genetic diversity and forensic investigation of the threatened palm species Butia eriospatha. Conservation Genetics 15: 441-452.

Negrini, R., L. Nicoloso, P. Crepaldi, E. Milanesi, R. Marino, D. Perini, L. Pariset, S. Dunner, H. Leveziel, J. L. Williams and P. A. Marsan (2008): Traceability of four European Protected Geographic Indication (PGI) beef products using Single Nucleotide Polymorphisms (SNP) and Bayesian statistics. Meat Science 80: 1212-1217.

Neophytou, C. (2014): Bayesian clustering analyses for genetic assignment and study of hybridization in oaks: effetcs of asymmetric phylogenies and asymmetric sampling schemes. Trees Genetics and Genomes 10: 273-285.

Neophytou, C. and H-G. Michiels (2013): Upper Rhine Valley: A migration crossroads of middle European oaks. Forest Ecology and Management 304: 89-98.

Neophytou, C., S. M. GÄrtner, R. Vargas-Gaete and H-G. Michiels (2015): Genetic variation of Central European oaks: shaped by evolutionary factors and human intervention? Trees Genetics and Genomes 11: 79 . 
Olalde, M., A. Herran, S. Espinel and P. G. GoICOECHEA (2002): White oaks phylogeography in the Iberian Peninsula. Forest Ecology and Management 156: 89-102.

OGDEN, R. and A. LINACRE (2015): Wildlife forensic science: A review of genetic geographic origin assignment. Forensic Science International-Genetics 18: 152-159.

Petit, R. J., C. Bodenes, A. Ducousso, G. Roussel and A. KREMER (2004): Hybridization as a mechanism of invasion in oaks. New Phytologist 161: 151-164.

Petit, R. J., S. Brewer, S. Bordacs, K. Burg, R. Cheddadi and E. CoART et al. (2002a): Identification of refugia and post-glacial colonisation routes of European white oaks based on chloroplast DNA and fossil pollen evidence. Forest Ecology and Management 156: 49-74.

Petit, R. J., U. M. Csaikl, S. Bordacs, K. Burg, E. CoArt and J. CotTrell et al. (2002b): Chloroplast DNA variation in European white oaks Phylogeography and patterns of diversity based on data from over 2600 populations. Forest Ecology and Management 156: 5-26.

Petit, R. J., C. Latouche-Halle, M. H. Pemonge and A. KREMER (2002c): Chloroplast DNA variation of oaks in France and the influence of forest fragmentation on genetic diversity. Forest Ecology and Management 156: 115-129.

Petit, R. J., E. Pineau, B. Demesure, R. Bacilieri, A. Ducousso and A. Kremer (1997): Chloroplast DNA footprints of postglacial recolonization by oaks. Proceedings of the National Academy of Sciences of the United States of America 94: 9996-10001.

Plomion, C., J-M. Aury, J. Amselem, T. Alaeitabar, V. BARBE and C. Belser et al. (2015): Decoding the oak genome: public release of sequence data, assembly, annotation and publication strategies. Molecular Ecology Ressources doi: 10.1111/17550998.12425

Rannala, B. and J. L. Mountain (1997): Detecting immigration by using multilocus genotypes. Proceedings of the National Academy of Sciences of the United States of America 94: 9197-9201.

Sebastiani, F., S. Carnevale and G. G. Vendramin (2004): A new set of mono- and dinucleotide chloroplast microsatellites in Fagaceae. Molecular Ecology Notes 4: 259-261.
Slade, D., Z. Skvorc, D. Ballian, J. Gracan and D. PAPES (2008): The Chloroplast DNA Polymorphisms of White Oaks of Section Quercus in The Central Balkans. Silvae Genetica 57: 227-234.

Steinkellner, H., C. LeXer, E. Turetschek and J. GLossL (1997): Conservation of (GA)(n) microsatellite loci between Quercus species. Molecular Ecology 6: 1189-1194.

Streiff, R., A. Ducousso, C. Lexer, H. SteinKellner, J. Gloessl and A. Kremer (1999): Pollen dispersal inferred from paternity analysis in a mixed oak stand of Quercus robur L. and Q. petraea (Matt.) Liebl. Molecular Ecology 8: 831-841.

Streiff, R., T. LABbe, R. BACilieri, H. SteinkellneR, J. Glossl and A. KRemer (1998): Within-population genetic structure in Quercus robur L. and Quercus petraea (Matt.) Liebl. assessed with isozymes and microsatellites. Molecular Ecology 7: 317-328.

Vidalis, A., A. L. Curtu and R. Finkeldey (2013): Novel SNP development and analysis at a NADP+ - specific IDH enzyme gene in a four species mixed oak forest. Plant biology 15: 126-137.

Wasser, S. K., L. Brown, C. Mailand, S. Mondol, W. Clark, C. Laurie and B. S. Weir (2015): Genetic assignment of large seizures of elephant ivory reveals Africa's major poaching hotspots. Science 349: 84-87.

Weising, K. and R. C. Gardner (1999): A set of conserved PCR primers for the analysis of simple sequence repeat polymorphisms in chloroplast genomes of dicotyledonous angiosperms. Genome 42: 9-19.

YÜCEDAG, C. and O. GAILING (2013): Morphological and genetic variation within and among four Quercus petraea and $Q$. robur natural populations. Turkish Journal of Botany 37: 619-629.

Zanetto, A., G. Roussel and A. Kremer (1994): Geographic variation of interspecific differentiation between Quercus robur L. and Quercus petraea Matt. Liebl. Forest Genetics 1: 111-123.

Ziegenhagen, B., S. Liepelt, V. Kuhlenkamp and M. Fladung (2003): Molecular identification of individual oak and fir trees from maternal tissues of their fruits or seeds. Trees-Structure and Function 17: 345-350. 